\title{
Patent in Biomedicine
}

Keywords: Patent; Medicine; Biotechnology; Invention; Intellectua property; Law

\begin{abstract}
Intellectual property is a collective name for the ownership of the results of the human creative mind. Although it refers to intangible property, intellectual property entitles the holder of copyright or patent, trademark, industrial design and another that has this right as a material property and thus benefit from their intellectual labor. State administrative act recognizes the exclusive right to the use and disposal of intellectual creations creativity protected by special laws for any form of industrial property. One of these forms is a patent, patent Law and protection under consideration in this paper.
\end{abstract}

\section{Introduction}

The process of creating the invention begins with the inventive idea, which could dawn of the moment thing, but the maturation of the invention generally is lengthy and complex. From the idea to its transformation into marketable product often requires research, study, experimental verification and correction of the prototype, professional, and expert and processing to the final version of the invention functional, ergonomic, aesthetic and technological solutions meet. Impeccable functionality and good design and technology are necessary, but not sufficient conditions for the success of the invention on the market, so many inventions never experience placement, despite their entire efforts inventor.

\section{Intellectual Property}

Intellectual Property Rights (IPRs)-patents, copyright, trademarks and so on exist to prevent those who do not have the right holder's license from producing and trading in certain goods or services where otherwise they would be entitled to do so [1]. IPRs indirectly provide their owners with a freedom to trade in a market without direct competition from those with whom they have no connection.

The products of the human mind are intangible assets, whose value in duplication, use and presentation to other peoples, so they cannot be protected by hiding, imprisonment or other measures of physical protection [2]. In order to protect this type of goods and thus stimulate human creativity that contributes to overall social development has developed an appropriate system of legal protection of intellectual property.

Unauthorized use or reproduction of the intellectual property is a violation of rights and the right of the owner to access, use and obtain the benefits, protects the assets and the institutions of the legal system.

In the legislation exists two groups of conditions-conditions that the invention must meet in order to obtain patent protection and conditions to be meet by the applicant in order to qualify for a patent [3]. The first group of conditions called material conditions, given the fact that they relate to the substantive content of the invention. Conditions relating to when they had to obtain legal protection and obtaining a patent document that serves as proof of the existence of

\section{Journal of Clinical Trials \& Patenting}

\author{
Siniša Franjić* \\ Faculty of Medicine, Josip Juraj Strossmayer University of Osijek, \\ Republic of Croatia \\ *Address for Correspondence: \\ Dr. Siniša Franjić, Faculty of Medicine, Josip Juraj Strossmayer \\ University of Osijek, Osijek, Republic of Croatia, Tel: ++385-31-51-28-00; \\ Fax: ++385-31-51-28-33; E-mail: sinisa.franjic@gmail.com \\ Submission: 24 December, 2016 \\ Accepted: 20 January, 2017 \\ Published: 25 January, 2017 \\ Copyright: @ 2017 Franjić S. This is an open access article distributed \\ under the Creative Commons Attribution License, which permits \\ unrestricted use, distribution, and reproduction in any medium, provided \\ the original work is properly cited.
}

the patent and the right of a specific person on the patent, called the formal requirements. Material conditions can be called positive, legal requirements, because only an invention that meets all the positive legal requirements can become a patent.

\section{Patentability in Biotechnology}

The dynamic development of modern biotechnology has led to the standard model patent which has long been prevalent in comparative patent law [4]. Biotechnology of microorganisms is quite early come into the sphere of patent law, while the biotechnology higher organism that long was not the case. Under pressure from powerful multinational companies approached the revision of the patent law in a way that patent protection in this area significantly expanded especially towards the protection of what is traditionally considered a scientific discovery. In the first phase there is a patent protecting the microorganisms that are only isolated from the environment to the end of the biological material which is isolated from the human body in terms of patent protection fully equal with the material or substance that is isolated from other natural environment, with a condition that is clearly defined its purpose.

Traditional biotechnology includes biological methods of plant breeding and use of animals and microorganisms for the production of food, beverages and for some other biological processes such as decomposition waste and similar procedures. In addition to traditional biological processes (selection, crossbreeding and mutation), modern biotechnology includes cloning living beings, genetically engineering and tissue engineering. Also according to the traditional division, the areas of biotechnology were treated to microbiology and biology of higher organisms. The development genetic engineering, especially in the context of situation that in this area all the innovations and in higher organisms carry out the micro level through the so-called manipulation of genes, this division is pretty much lost on character. In legal literature, inventions in the field of biotechnology are considered those in which the means of inanimate nature influence the course of biological processes; biological means affect inanimate matter and biological agents influence the course of biological process products. The findings from this area find use in the pharmaceutical 
industry, agriculture, food industry, ecology as well as in some other industries.

In recent decades, this area has experienced great expansion, which had to gain and its legal expression through appropriate international treaties and national laws. However, some relics of traditional biotechnology division have left their mark in patent legislation. Long prevailing viewpoint in comparative Patent law was that this type of inventions because relates to live the matter cannot be the subject of patent protection. However, patent law is gradually changed and patent protection was first recognized the so-called fermentation procedures based on the metabolic activity microorganisms (processes for preparation of alcohol, beer, yeast and vinegar), while are so-called higher organisms remain outside patent protection.

What characterizes this area are some specifics in relation to the traditional model of patent protection, which is next to the subject matter of protection in particular relating to the novelty of the invention, the attitude towards scientific discovery, description of the invention and its repeatability, limitations of patents that are related to the biological material, the border patent specifically the protection. Human genetics, as well as the possibility of a sui generis protection of plant varieties, and on an ethical as well as ecological issues relating to the matter.

Like fast food chains, the trademarks of multinational drug companies are often well known, and their products recognizable as commodities that can enhance people's lives in innumerable ways [5]. But drugs are also increasingly considered vital to the most basic aspects of our quality of life, and in some cases, our survival. For people suffering from debilitating illness, drugs are akin to basic necessities, like food and water that can preserve, improve or prolong life.

The rise of a biotechnology industry, often comprising companies spun-off from university laboratories, has offered additional opportunities for the discovery of new classes of drugs, and-coupled with the emergence of firms specialized in clinical trials-is resulting in significant changes in the structure of the industry [6]. Universities themselves, particularly in the United States, have become key players in the development of new biotechnologies. Intellectual property rights have been central in this development, and increasingly universities have developed extensive patent portfolios.

It should be pointed out that all over the world appear certain problems regarding the protection of Patent medicines and medicinal substances. Since the purpose of the drug to treat diseases of humans and animals or preventive effect against the disease, many believe that for ethical reasons it is not permissible that the drug patent limits [7]. The drug should be accessible to everyone who needs it.

Here we should point out that the direct, individual preparation of the drug in pharmacies to individual doctor's prescription, as well as the action of putting both the signature authorization, are exempt from the effects of the patent [8]. The general ethical and health interest requires that the patent for the drug is not an obstacle to the drug in individual cases produced and put into circulation. This is political and legal reason which is located in basic of this exception.
To the drug found in the market, it is necessary to implement the regulation. This is needed to protect patients from bad and harmful drugs that do not meet current standards. The regulation includes a number of activities. Keywords are: testing of drugs (pharmaceutical, non-clinical and clinical), production of medicines, the assessment and approval of drugs, inspection of production and supply chains, issuing licenses for import/export, production, distribution and retail of drugs, monitoring of adverse effects of medicines (pharmacovigilance) the quality control laboratory, approving and monitoring clinical trials and monitoring of good clinical practice and control of information and advertising of medicinal products [9]. And the manufacturer and regulatory authority have roles in regulating drugs.

Access to unique research resources, such as biological materials and reagents, is vital to the success and advancement of science [10]. Many research protocols require assembling a large and diverse set of materials from many sources. Yet, often the process of finding and negotiating the transfer of such materials can be difficult and timeconsuming. The ability to locate materials based on their descriptions in journal articles is often limited by lack of sufficient information about origin and availability, and there is no standard citation for such materials. In addition, the process of legal negotiation that may follow can be lengthy and unpredictable. This can have important implications for science policy, especially when delays or inability to obtain research materials result in lost time, productivity and research opportunities. These transactional barriers for material transfer may ultimately have more impact on the productivity of basic laboratory science than concerns related to patents or other intellectual property.

This raises one logical question: whether the protection of any form of intellectual property rights is necessary in the field of biotechnology? The answer is yes and this is because the intellectual property protection, mainly patent development in the field of biotechnology drugs. By providing the prospect of exclusive marketing of new diagnostics, tools, and therapies, they motivate the investment necessary to fund what is usually a long and expensive development process [11]. But patent law itself is a complex, controversial, and rapidly evolving mechanism.

As a condition of receiving drug patents-a form of intellectual property right of particular import to the pharmaceutical industrydrug companies might be required to contribute a certain percentage of future sales to a global fund for subsidizing purchases of medications by the health services of poor countries [12].

Clarification of the structure of DNA directed the biological science to technological discipline that is now called biotechnology. Today, there is no doubt that molecular biology, molecular genetics, and biotechnology are disciplines that provide technical improvements and solutions for technical problems [13]. Hence, the results provided by these disciplines are vulnerable to patent protection such that the inventors can commercialize their finding under a limited exclusivity. The latter appears to be particularly appropriate because bringing a biotechnological invention into the market is often a very developmentally intense project.

Biotechnology involves enormous investments in experiments 
[14]. While scientific improvements developed dizzying, introduction of products and processes resulting from these improvements is slow.

It should be noted that in parallel with the patents and the patentability of developing a new legal discipline-patent law, which is characterized by an extremely complex personality. Patent law is a complex subject [15]. Not only does it require an understanding of the science, it also requires an understanding of how the science fits within the law. What makes it even more complicated is that it is constantly evolving. As our understanding of science continues to grow, so do the patent laws. One area that sees a great deal of change is the area of medical technology, which includes pharmaceutical drugs, vaccines, diagnostic tools, biomarkers, and the like. To understand the complexities of patent law and to adapt to its changes, we must have a deeper appreciation of exactly what patent law is and what it strives to achieve. Being able to appreciate the bigger picture is important to understanding how patent law has developed over the years and how it will continue to evolve.

\section{What can be Patented}

A patent may be granted for an invention in any field of technology, if it is new, involves an inventive step and is capable of industrial application [16]. The maximum period of protection is 20 years, which is comparatively short as compared to other intellectual property rights. But the monopoly conferred is strong. A patent does more than protect against copying. It prevents even independent devisers of the same idea from using that idea. To balance the strength of this right, a patentee is required to disclose the invention in the patent specification, which is available to the public. In modern systems, patents are intended to encourage innovation, and to promote developments which build on that inventiveness. The aim is that the grant of a patent will act as an incentive to inventors, who will consider the rewards sufficient to make it worthwhile disclosing their invention. Information about the latest technical advances thus becomes available for public consultation, thereby increasing efficiency, and in turn prompting further inventions. Of course, this is a very simple, summary account of a much more complex mechanism. There is a wealth of material exploring the appropriateness and effectiveness of the incentives offered by patent systems.

Thus, the patent shall be granted for any invention, in any field of technology which is new, involves an inventive step and capable of industrial application. Under the law, a patent is granted for an invention relating to:

1. The product, consisting of biological material or containing biological material,

2. The process by which the biological material is produced, processed or used,

3. Biological material isolated from its natural environment or produced by a technical process, even if it previously occurred in nature.

Biological material means any material containing genetic information and capable of reproducing itself or being reproduced in a biological system.

The invention, which is related to plants or animals shall be patentable if the technical feasibility is not confined to a particular plant or animal variety and if the process of achieving the present invention is not essentially biological.

Process for the production of plants or animals is essentially biological if it entirely consists of natural processes such as crossing or selection.

The invention does not particularly consider:

1. Discoveries, scientific theories and mathematical methods,

2. Aesthetic creations,

3. The rules, instructions and methods for performing mental acts, playing games or doing business,

4. Presentation of information and

5. Computer programs.

\section{What Cannot be Patented}

Excluded from patent protection are:

1. The invention of animal and plant species and essentially biological processes for the production of plants or animals other than non-biological invention and microbiological processes and products resulting from such processes, whereby, under the microbiological process means any process involving or performed upon microbiological material or whose product microbiological material.

2. Human body, the various stages of its formation and development or the simple discovery of one of its elements, including the sequence or partial sequence of a gene. The invention that relates to an element isolated from the human body or produced by a technical process, including the sequence or partial sequence of a gene may be patentable, although the structure is equal to that of a natural element. The industrial application of a sequence or partial sequence of a gene must be disclosed in the patent application as originally filed.

3. Inventions related to diagnostic or surgical procedures or methods of treatment practiced directly on the human or animal body, than products, in particular substances or compositions used in such methods.

Shall not be considered un patentable where their commercial exploitation would be contrary to public order or morality, but not only because such exploitation is prohibited by law or regulation.

Here we should point out the possibility of patenting inventions in the European Union. European patents granted for inventions that are new, involve an inventive step and are industrially applicable. The invention can be in any field of technology.

European Patent Convention does not define the meaning of the invention, but gives a non-exhaustive list of items and activities that cannot be regarded as inventions which are expressly excluded from patentability [17].

The first area of the computer programs, which are not regarded as inventions if protection is sought for them as such. However, the 
computer program is not excluded from patentability under Article 52 of European Patent Convention if the programs, working on the computer, realize further technical effect which goes beyond the "normal" physical interaction between the program (software) and computers (hardware). An example of a further technical effect is a case where the program serves to monitor the technical procedure or operated by the action of the technical devices. The internal functioning of the computer itself under the influence of the program could also bring about such an effect.

If the computer program itself is not excluded, it does not matter whether an application for protection as such, as a data storage medium on which the software is stored as a method or as part of a computer system. Thus, computer programs are not automatically excluded from patentability.

Another area of the surgical or therapeutic methods for treatment of the human or animal body and diagnostic methods practiced on the human or animal body. The exception to patentability does not apply to products, substances and mixtures which are used in such processes, for example, drugs or surgical instruments. Any substance or mixture does specifically treat the presumption news: even known substance or composition may be patented for further use in the medical or veterinary purposes, provided that such use is novel and inventive.

This exception does not exclude the patentability of other methods of treatment of live human beings and animals; treatment of body tissues after they were removed from the human or animal body and diagnostic methods applied to such tissues are patentable provided that the tissues are not returned to the same body.

The third area of the plant and animal species and essentially biological processes for the production of plants or animals, which are expressly excluded from patentability. In the case of plant species, a special form of protection is available in most contracting states and under EU law. A method of preparing plants or animals is essentially biological process, if it entirely consists of natural processes such as crossing or selection.

The exception does not apply to microbiological processes or on the products thereof. In general, biotechnological inventions are also patentable if they concern biological material which is isolated from its natural environment or produced by a technical process, even if it previously occurred in nature.

The last area of inventions excluded from patentability because their commercial exploitation would be contrary to "order public" or morality. In particular, patents are not recognized in respect of processes for cloning human beings, processes for modifying the germ line genetic identity of human beings, uses of human embryos for industrial or commercial purposes, processes for modifying the genetic identity of animals which are likely to cause them suffering without any substantial medical benefit to man or animal, and also animals resulting from such processes.

The invention is not considered in particular:

1. Processes for cloning human beings,
2. Procedures for modifying the germ line genetic identity of human beings,

3. The use of human embryos for industrial or commercial purposes and

4. Processes for modifying the genetic identity of animals which are likely to cause them suffering without any substantial medical benefit to man or animal, and also animals resulting from such processes.

Recent developments in the life sciences-genetic engineering, cloning, and manipulation of cell lines, exploitation of genetic resources-have sparked vigorous debate about the ethical dimension of these new technologies [18]. The reasons are not hard to identify. Life sciences research literally touches on issues of life and death.

Within these disciplines lies huge biotechnological potential which is due to the general well-being, certainly need to protect some of the forms of intellectual property.

The European Patent Convention is by its nature an international agreement which is directly applicable in the contracting states so that only a few of the provisions contained in the national law of the patent refers to the direct application of the Convention and regulates the effects of European patent applications and European patents in the contracting states.

Although it does not contain rules that are Contracting States shall their national patent law to agree with the provisions of the Convention even contains rules on the need for harmonization of national patent rights in the Contracting States, particularly those substantive nature, the European Patent Convention has a key role in the harmonization of substantive patent law of the Contracting States [19]. The parallel with the ratification of the Convention any Contracting State spontaneously adjusts the provisions of its national patent system by accepting the substantive rules of the Convention. At the same time, authorities of the Contracting States which are still responsible for the actions of recognition patents at national and/or international application, as well as courts have jurisdiction for actions relating to patents, generally accepted administrative practices and interpretations of patent standards such as novelty, inventive step, industrial applicability, an expert in the art and others. Which is developed body of the European Patent Office, The success of the European Patent Convention is also reflected in the fact that its harmonizing effect influences the development of patent law and beyond the countries that have acceded to the ratification.

\section{Exclusive Patent Rights}

The patent owner is authorized to use the protected invention.

Without permission of the patent owner to any other person is forbidden:

1. Making, offering for sale, selling, using, exporting or importing and stocking for such purposes, the product carried out according to the invention,

2. Using the process of the invention, or offering the use thereof,

3. Offering for sale, selling, using, exporting or importing and stocking for such purposes a product directly obtained by the 
process of the invention.

Without permission of the patent owner to any other person is prohibited from offering and supplying the product (substance, composition, part of the device), which makes an essential element of the invention to persons not entitled to exploit the invention, if the offerer or the supplier knows or the circumstances of the case should be know that this product is intended for putting into function the invention of another. These provisions do not apply if the product being offered or delivered to the common market, unless the provider or supplier encourages others to take the actions described.

In the absence of evidence to the contrary, it is considered that the product obtained by a protected process, if it is new and it is probable that the product obtained by a protected process, and that the patent holder could not, despite reasonable efforts, to determine the process actually used. The probability that the product obtained by a protected process exists particularly when the protected process is the only process known.

If a patented biological material possessing specific characteristics as result of the invention, the exclusive rights shall also apply to any biological material derived from that biological material through propagation or multiplication in an identical or divergent form with identical characteristics.

If a patented process that allows the production of a biological material possessing specific characteristics of the invention result, the exclusive rights shall also apply to biological material directly obtained through that process and to any biological material derived from that biological material through propagation or multiplication in an identical or divergent form with identical characteristics.

If a patented product containing or consisting of genetic information, the exclusive rights shall also apply to all material, in addition to the human body, the various stages of its formation and development and the simple discovery of one of its elements, including the sequence or partial sequence of a gene, in which the product is incorporated and in which the genetic information is contained and performs its function.

\section{Conclusion}

Intellectual property in the broadest sense means a set of rights resulting from intellectual activity in the industrial, scientific, literary and artistic fields. Members protect intellectual property for two main reasons. The first is to provide legal protection through the preservation of the moral and economic rights of authors over their creations and to allow the public access to them. The second is to promote, as a deliberate act of government policy, creativity and development programs should promote fair competition and thus participate in economic and social development.

In today's global economy, economic progress does not come so much from natural sources, or the production of industrial goods as much from the "production" of new ideas and consequently-new products. Knowledge and innovation play a crucial role in the growth of the world economy. Differences between rich and poor countries in terms of development of science, technology and knowledge are more important than differences in income. Although the development of the information society has been a change in the forms of production and products against industrial society, refers to the production remained on the same basis/principles of ownership. Information and knowledge are becoming important market goods with the appropriate price. Ownership based on knowledge and information as well as products of the human intellect is the intellectual property to which the patent is one of the foundations.

Patents, copyrights, trademarks and other products of the human mind, very often they are the objects of business relationships, but at the same time as a special form of property entered into traders or companies. The use of these rights can enable economic growth, but also affect the national wealth of a country. Their placement often means the degree of success of their respective holders and owners. It should be pointed out that all products of the human mind formed in this way, very often factors unfair fight its competitors. Intellectual property rights (of course, and patents), its real significance given at the time when they are in traffic and become available to a larger number of subjects.

\section{References}

1. Cornish WR (2000/2006) The free movement of goods I: pharmaceuticals, patents and parallel trade" in Goldberg R, Lonbay J (Eds), Pharmaceutical medicine, biotechnology and European Law. Cambridge University Press, Cambridge, pp. 11

2. Franjić S (2015) Intellectual property and computer crime, Trends in the development of legal science at the present stage, Proceedings of International scientific-professional conference devoted to the 40th anniversary of the Faculty of Law KemSU, Kemerovo, Russian Federation.

3. Raičević V (2010) Pravo industrijske svojine (Industrial Property Law), Pravni fakultet za privredu i pravosuđe, Novi Sad, pp. 38.

4. Šarac J (2016) Specifičnosti zaštite prava intelektualne svojine u oblasti biotehnologija (Characteristic of the Protection of Intellectual Property Rights In the Field of Biotechnology).

5. Lenk C, Hoppe N, Andorno R (2007) Ethics and law of intellectual propertyCurrent problems in politics, science and technology, Ashgate, Hampshire, pp. 48.

6. (2006) Public health-Innovation and intellectual property rights, World Health Organization, Geneva, pp. 25.

7. Verona A (1978) Pravo industrijskog vlasništva (Industrial Property Law), Informator, Zagreb, pp. 84.

8. Marković SM (2007) Pravo intelektualne svojine (Intellectual Property Law), Magistrat, Pravni fakultet Univerziteta u Sarajevu, Sarajevo, pp. 137.

9. Tomić S, Sučić AF, Martinac Al (2010) Reguliranje lijekova u Hrvatskoj - doprinos javnom zdravstvu (The regulation of medicines in Croatia-A contribution to public health), Kemija u industriji, 7-8.

10. Nguyen $T$ (2009) "Case 6. The science commons material transfer agreement project - A standard licence clearinghouse?” In: Overwalle GV (Ed): Gene patents and collaborative licensing models - patent pools, clearinghouses, open source models and liability regimes, Cambridge University Press, Cambridge, pp. 143.

11. Barfield C, Calfee E (2007) Biotechnology and the patent system-balancing innovation and property rights. The AEI Press, Washington DC, pp. 24.

12. Buchannan A, Decamp M (2009) Responsibility for global health. In: Buchannan A (Ed), Justice \& Health Care (Selected Essays). Oxford University Press, New York, pp. 223.

13. Hübel A, Schmelcher T, Storz U (2012) Biopatent law-patent strategies and patent managemen. Springer, London, New York, Duesseldorf, pp. 2.

14. Cornish W (2008) Intelektualno vlasništvo-sveprisutno, ometajuće, nebitno? 
Citation: Franjić S. Patent in Biomedicine. J Clin Trials Pat 2017;2(1): 6.

ISSN: 2573-3834

(Intellectual Property: Omnipresent, Distracting, Irrelevant?), Omnilex, Zagreb, pp. 44

15. Brougher JT (2014) Intellectual property and health technologies-balancing innovation and the public's health, Springer, New York.

16. Seville C (2009) EU Intellectual property law and policy. Edward Elgar Publishing Limited, Cheltenham, Northampton, pp. 70.
17. European patent convention. European Patent Office, 2016.

18. (2016) Intellectual property and bioethics-An overview. World Intellectual Property Organization.

19. Vučković RM (2011) Hrvatska i Makedonija u europskom patentnom sustavu» (Croatia And Macedonia In the European Patent System), Zbornik radova Pravnog fakulteta u Zagrebu, 2/2011. 